\title{
NEFL wt Allele
}

National Cancer Institute

\section{Source}

National Cancer Institute. NEFL wt Allele. NCI Thesaurus. Code C88042.

Human NEFL wild-type allele is located in the vicinity of $8 p 21$ and is approximately $6 \mathrm{~kb}$ in length. This allele, which encodes neurofilament light polypeptide protein, plays a role in both the establishment and maintenance of axonal and dendritic structures. Mutation of the gene is associated with Charcot-Marie-Tooth disease types $1 \mathrm{~F}$ and $2 \mathrm{E}$. 